\title{
A Space for Tears
}

\author{
Lucia Kramárová \\ ArtEZ University of the Arts, Arnhem, the Netherlands
}

\begin{abstract}
"A space for tears" explores the relations of the phenomenon of absence and performance and their implications for both art and life practices. The connections are uncovered through the exploration of the forms and modalities of absence, the positionality of absence as a constitutive element of performance, the affinity of absence and the questions of embodiment and the interconnection death and mourning ritual with performance. The driving force of this research is the need for (re)establishing a healthy relationship with absence, which would not be confined exclusively to the artistic realm. The paper is conceived as a hermeneutic study in a polemic tone, utilizing theoretical and literary works of poetry and prose as well as folk literature as equal sources. The plurality of sources and especially their form and origin ties in with the expansion beyond art practices, which bids to consider alternative repositories of knowledge. Capturing and keeping the fluidity and ambivalence of the researched topics is a key feature of the research, which remains thoroughly visible. The study keeps the weave of conclusions open, ready to be correlated with practice.
\end{abstract}

Keywords: absence, performance, ruin, mortuary ritual, touch

The relationship of absence-as-exception ${ }^{1}$ and performance is structurally essential to the constitution of performance and multivalent in its variations. When performance is defined as the repetition of behaviour, absence-as-exception is manifest not only within the relationship to the material, which is repeated, but also in relation to the repetition. A perfect repetition of any given behaviour does not exist in the human capacity, which results in the disappearance of the "original" behaviour for good rendering each subsequent repetition exceptional. Even though these behaviours may continue to impact the world in an array of durations, the specific behaviour ceases to exist once performed. Thus, performance concerns itself with revision, re-invention, re-initiation, revisiting, or substitution rather than cut and dry repetition, operating on somewhat alchemic principles: "The scientist continues, the alchemist repeatedly begins" (Bachelard, 2010). This process may retain breathtaking preciseness and functionality in the course of time, but the fact remains that each instance of such repeated beginning is fully transient.

These disappearances markedly evoke the syndrome of the door - the phenomenon of forgetting prompted by leaving one room and entering another. The explanation for this "doorway forgetfulness" is the fact that the

Lucia Kramárová, B.A., master student, Master in Theatre Practices, ArtEZ University of the Arts, Arnhem, the Netherlands.

1 A notion derived from the interpretations of the word absence in the English, Czech, and Slovak language (ranging from not occurring, nonexistence as such, through ruined anticipation, not finding, missing, not fulfilling an obligation, not showing up, opting out of participation and nonaction to a failing of the senses in the form of an instance, condition, opportunity, season, requirement, action, etc.) with the uniting element of these nuances being the notion of an exception to an established rule and thus a phenomenon that is essentially relational. In this context, I find it crucial to remember not to confuse the contradictory for the absent in the name of simplifying categories as "doctors most commonly get mixed up between absence of evidence and evidence of absence"- not understanding something does not mean it is not there. 
transition from one room to the other figures in the minds eye as a certain "border of events", which separates the activity taking place before the doorstep and from the activity behind it. Performance functions in a similar fashion, due to sharing the characteristic of an action in transition. It is an act of the border, a liminal act and therefore the world before and after conducting a performative act is a world in entirely different conditions.

Doors are eternal children. They grow wide-open, they live only open. And by each closing they return to their inception. By each doorway we enter deeper into the world. The world is not different. Only the state of the world is different. Different opportunities. There are doors in between them. And in between us. They lead to us. (Štrpka, 1985)

The already shaky "original" thus becomes a blind spot, aiding the formation of perspective. "The foundation of the stand-in is the vanishing point: the hole that launches the illusion of perspective (...)" (Phelan, 2009). The absence of the original therefore not only further initiates the need for repeated beginnings in performance, but also allows insight into the entire process. The empty space of the original "pulls the eye in" and forms a framework of perception. In each instance of performance, absence must be accepted, overcome, and thus repeatedly confirmed - bringing forth remembrance and simultaneous forgetting of the original. The "missing" is voided and reinstated again. In the words of Joseph Roach:

[Performance] stands in for an elusive entity that it is not, but it must vainly aspire both to embody and replace. Hence flourish the abiding yet vexed affinities between performance and memory out of which blossom the most florid nostalgias for authenticity and origin. Where memory is, notes theorist-director Herbert Blau, theatre is. (Roach, 1996)

In addition to describing the relationship between performance and the original, Joseph Roach points out the familiarity of performance and memory. Both entities are dependent on repetition and assume a specific relationship to the past, which boldly resists objectivity. Both are partial to efforts of tearing the human subject away from the void of uncertain origins of performative acts and taking roots. As Eugenio Barba says: "Memory is the spirit of our acts" (Pilátová, 1994), and performance eagerly invokes these spirits. Tadeusz Kantor thinks in similar contours, strongly underlying not only the axis between performance and memory, but more pronouncedly the relations between performance and death:

The metaphysical aspect of illusion, until now ignored, is repetition. Almost a ritual.

Atavistic gesture of a human, who at the threshold of his history longs to confirm something.

Do something for the second time,

in an artificial way,

at his own costs - human,

repeat something, which was once already created—by Gods,

expose oneself to their jealousy and revenge,

undertake risk

face expected defeat

know well, that these works will be in vain,

without prospects in the future,

perishable.

(...)

Ritual

as if on another side of life,

mercenary of death.

We state clearly and openly

that gloomy procedure of REPETITION

is a protest and challenge. 
Now it may be easily added:

is the es s e n c e of art.

(Kłossowicz, Kantor, Lexová, \& Hyvnar, 2017)

I would therefore like to establish a nonlinear triad of performance-memory-death, which will be crucial to my further thought. However, before I dive deeper into this very triad, I feel the need to invest in exploring an element undisputedly present in the quotations of Roach and Kantor and that is doubt and even anxiety born from repetition and its consequences. Both Roach and Kantor openly call out the efforts of performance as somewhat pointless and vain; they stress the condition of the human subject being doomed to sustaining this activity and present it as something warped. I do not consider it my role to dispel these claims, on the contrary, I believe that this vanity may become a constructive quality in the context of understanding performance as a ruin. Édouard Levé offers us a beautiful definition of a ruin and its attractiveness:

A ruin is an accidental aesthetic object. If it becomes beautiful, this was certainly not the intention. A ruin is not constructed or maintained. The tendency of a ruin is to crumble down into a heap. The most beautiful parts remain standing despite their wear and tear. The memory of you is what stays up, your body what subsides. Your ghost remains upright in memory, while your skeleton is decomposing in the earth. (Levé, 2011)

And Jerzy Grotowski brings it into relation with theatre, but I believe a transposition onto performance at large is not too far fetched:

I think theatre ought to be seen as an abandoned house, as something useless, something that is in fact not necessary. We do not want to believe yet, that only ruins remain; because it may still function. (...) But look-in the beginning of our era truth seekers looked for abandoned places to realize their life mission exactly there. (Grotowski \& Ertlová, 1999)

Performance-as-ruin holds within its potentiality unmistakable gravitas, but it is not limited by the image, a leak-proof whole. It is full of assurance and simultaneously allows freedom of movement and interpretation stemming from its ambiguity and incompleteness. It forms a strong bond to the past as well as presenting clearly the deterioration of the historical image. It consorts with emptiness and caducity as well as fullness and firmness. It is not self-centred but is undoubtedly proud. It knew people but enjoys solitude. Performance-as-ruin connects the horizontal to the vertical through its allegiance to the earth as well as the heavens. And seemingly vain repetition, which resides in performance-as-ruin, may become unexpectedly beautiful and stunningly functional; keeping its strength, liberated from the demands and pressure of the maintained and official. "In this improvisatorial behavioural space, memory reveals itself as imagination" (Roach, 1996).

The door is wide-open. I can hear distant lively voices and children's laughter. Tender metal clanging. Fine whistling. Maybe the sound of vapour escaping a tea kettle. I slowly pass through the door and wish to awake. But I do not sleep. There is no other reality. (Štrpka, 1985)

One who passes through the doors and embraces absence-as-exception in acting-as-beginning-again in performance-as-ruin, must be bold and equipped with rather sensitive tools. One of the handiest may be a body. A body, which touches and guarantees, as Peggy Phelan reminds us:

(...) we are framed, arrested in an illusion, a theatre of substantiation, and that the authenticity can only become truly real through the agency of a stand-in. The proof of Christ's resurrection cannot be authenticated by God: Thomas must play this other part. (Phelan, 2009) 
To consider that in this context only Thomas is the only one in doubt would be largely insufficient. Christ himself after his resurrection is unsure of who he is and what is his current relationship to the men, whom he tried to forge a collective body with before his crucifixion. Uncertainty of the ontology of Christ's body underlines the uncertainty and tension of Christ as both a dramatic and a theological figure. Thomas must thus verify and substantiate by his touch not only for himself and the material world, but also for Christ, that the role Christ plays is real. The capacity of touch grounds the great questions of authenticity, legitimacy, origin, mission, etc., present in the story of Christ, just as in acting-as-beginning-again and transforms them into something quite specific upheld by actions, anchored in space and time. It is hence the body, "which enables us de facto access to the world" (Pilátová, 2017). More specifically, "in the body ideology meets transcendence - prancing from physiology to metaphysics" (Patočka \& Polívka, 1995). In the same way as for Thomas and Christ in their performative relations, also for us, in ours, it is often true that the one we long to speak to and create a relationship with the most, is absent. Touch, however, enables us to lead this much desired dialogue in substitution. Performance in this context assumes the function of a perpetual test —eternal verification within mimicry of substitution. "But a person who is possessed by passion, is never mistaken" (Bachelard, 2010).

In the introduction to her book Mourning Sex, Peggy Phelan describes an experience of tearing a paper model of the human anatomy out from her favourite encyclopaedia. She remembers experiencing a feeling of pride when she looked at the hole she created. The hole in the shape of a human, seemed to her as a better picture of the human anatomy than the original with red and blue drawn veins. Phelan considers this act to be her first within performative art. An act whose primary objective was to perform a disappearance of an undoubtedly present object. Crucial questions we ask ourselves remain crucial to us, because there is no one, who would answer them directly. An immediate and definite answer (like the paper model of the human anatomy) would devalue them and render them useless. Not knowing, resting within the space created by a wound, plays crucial role in performance and should as such not be a source of fear or apprehension. What we should really fear is: "the danger that the disaster should acquire meaning instead of a body" (Blanchot \& Smock, 1995).

But the question of reality or validity does not have to be the only question that Thomas and Christ pose to one another requiring touch as a guarantee. Did Christ fully believe that he truly was loved by God-the Father and apostles? Was he capable of accepting this fact only based on faith without physicality? Is it possible that Christ doubted to the extent he was human that he was loved?

"Do you love me" is a social question, a question of relation. It is fundamentally a question of perspective, of where one is in relation to the other (...). "Do you love me?" is a question, that can come to being only if the other is cast as a witness, an auditor, who will testify to the authenticity of interrogation as pure form, as that which is forever in question. "Do you love me?" is an elaboration on the questions "Do you see me?" and "Do you hear me?" and these three questions constitute the trinity of Western theatre, a set of technologies designed to ask what it means to be, and to make, embodied form from that which is not Present (Behind these questions is the question: “Will you die for me?”) (...). (Phelan, 2009)

The touching body is present to keep posing and answering the eternal question and posing it again in the same way performance complementarily remembers and forgets. The touching body guarantees the creation and upkeep of a relationship (by human standards) and is as such a reliant vehicle of performance, memory, and death. If I am to return to the image of Christ and Thomas, what resonates with me is a mutual wish:

I wish there was a treaty

I wish there was a treaty 
Between your love and mine

(2016)

In the negotiation of such a treaty, both parties are actors and spectators, both are a medium and a material to one another. And in a relationship established in this way, there is hope that "(...) reciprocity itself might be redemptive" (Phelan, 2009).

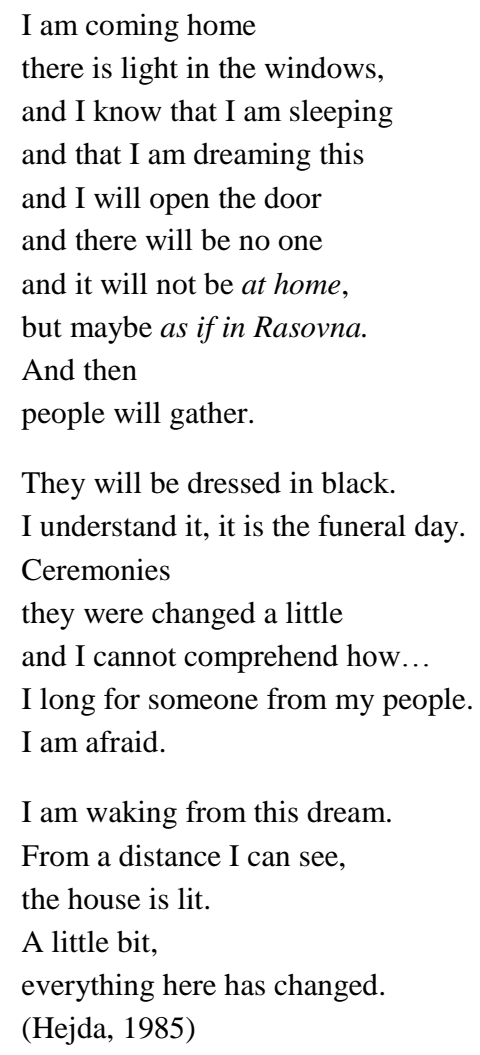

Zbyněk Hejda feels insecure in his dream: "Ceremonies / they were changed a little / and I cannot comprehend how... / I long for someone from my people. / I am afraid" (Hejda, 1985). I must admit to sharing his insecurity. Daily life attests to the fact that the contemporary human subject assumes significant distance towards the acknowledgment and perception of absence. Both consciously and subconsciously he pulls back from those aspects of life, which directly cultivate a relationship to absence. Specifically, the most literal and arguably most evocative events in this family - death and grieving. "If mourning is maimed, so is its associated entity, theatre. (...) Drama, like grief, requires performance: an interrupted play is as emotionally destabilizing as an incomplete mourning" (Maguire, 2016). By the reluctance to grieve fully, the contemporary is depriving themselves of the experience of connection and coming to peace with absence, therefore destabilising endeavours for creating performance by detaching them from reality.

We, sorrows,

we used to be a famous family. Ancestors were mining in the high mountains and people fell here and there a bit of beautiful old sorrow or veined, stoned anger of a volcano.

Yes, all that in those times. We were rich. 


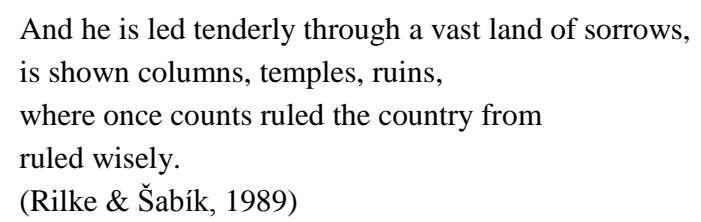

The ability to form a functional relationship requires to some extent a functional pre-image of such a relationship and an experience of living it. The relationship with absence is no exception to this prerequisite. In the approach to performance, I call for something what Gaston Bachelard calls complete psychology. "In other words, complete psychology must attach to the human what is detaching from him —unite poetics of dreaming with prosaic of life" (Bachelard, 2010). I suggest absorbing the triad of performance-memory-death not only as a metaphor or an intellectually satisfactory concept, but also as practice needed for achieving completeness in performance. Taking care of the dead normalizes acting with and through the non-material and makes a habit of it - a maintained practice. Performance and mourning rituals are after all both rituals of exception and mourning ritual in this context can serve as a stable basis for performance like the double bass for the orchestra. Without the stability of this foundation acting with the non-material in performance is exoticized, alienated, becomes a curiosity - it loses rhythm.

"Theatre, of course, has had a long romance with ghosts" (Phelan, 2009). Under the term ghosts, it is necessary to imagine not only a representation of the spirits of the dead, but the entire scale of evoking the incorporeal, invisible, and intangible, which is present in performance. Spirit in this extended perception stands for a translation (trānslātiō - transfer, from trans-over, + lātiō — carried) of absence. When spirits are invoked, whether in a mourning ritual or performance, emptiness is not nameless, shapeless, or immovable. A dialogue is opened. "In the name of memory, I hope I may be forgiven this nostalgia for presence, on the plea that, as a practical matter, the voices of the dead can speak freely only through the bodies of the living" (Roach, 1996). One prerequisite for the success of such invoking act is the touching body. The other is to be capable of accepting that spirits exist and are of utmost importance.

One of the basic functions of a mourning ritual is maintaining cognitive and affective continuity. As a mantic proverb says: "It takes more than death to make an ancestor" (Roach, 1996). Ancestors and other staples of continuity exist only in a relationship to the living, which must be established reciprocally tended. "The souls beg us for something" (Pilátová, 2016) and we beg them for something.

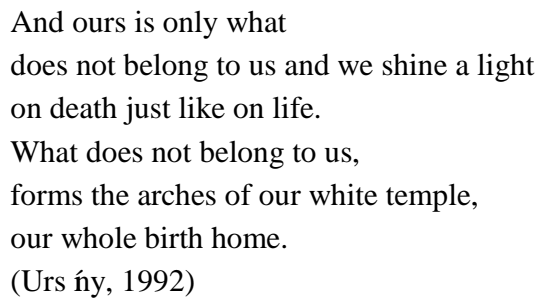

I consider it appropriate to sketch out an analogy between the continuity of living and perceiving living based on the relationship to deceased and the continuity of performance and perceiving performance founded on the relationship to a disappeared original. Let me in the name of this simile repeat that the disappearance of the original calls for beginning again and add that "nothing requires existence like a dead person" (Artaud \& Šerý, 1996). "Death as it is culturally constructed by surrogacy, cannot be understood as a moment, a point in 
time: it is a process" (Roach, 1996). Death can not be spoken of and dealt with otherwise than as a process, in eternal continuation. The duty which we have to her and she to us is always present.

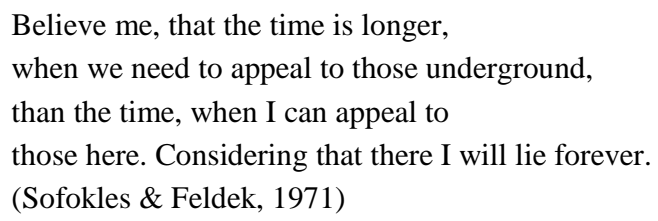

However, mourning ritual and performance share the ability to allow us to enter death on the terms of our own limited time, which is not eternal and unanchored. They give us the possibility to participate on death without remaining stuck in the forever. They allow us to "try death out". Exactly this aspect of being able to have a dry run with dying, leads to the place, where the borderline between performance and death can be delineated: "The dead one must rise and say, tomorrow we can do it better, up to this point performance is concerned, past this point it is something else" (Pilátová, 2017). Here the story of birth of the God Dionysus, one of the originators of European theatre, comes in handy. His mother, Semele, died, while she carried him in the womb and Zeus, his father, saved him by sewing the unborn child into his thigh, where the child was then born out of. Dionysus was thus "born twice". This version of the story gave birth to one of his surnames dimētōr- "of two mothers" (Semele and Zeus). In another version of this story (which Dionysus inherited from Zagreus - the "first Dionysus"), small Dionysus was torn to pieces and eaten by the Titans, who were turned into dust by Zeus, but the only thing remaining of Dionysus at that moment, was his heart. That heart Zeus sewn into his thigh, where Dionysus was born a second time from. From variations of this story, we may be led to the rituals of orphic ceremonies and in order to get "home" (to Central Europe), we may only call upon Leszek Kołankiewicz for help: "Dziady are a Polish equivalent of Dionysus" (Kołankiewicz, 1999). And subsequently Alexandra Navrátilová:

Similar nuisances, which were banned by the Western European penitential order, were found on our territory as well. As becomes clear from Homiliár collection of sermons of Opatovice and Chronica Boemorum, remembrance ceremonies were reproved, when our ancestors "according to pagan ritual took place on crossroads and junctions for resting of the souls, and in godless divertissement, they engaged in gaiety over their dead ones, calling out to empty shadows with masks on their faces". (Navrátilová, 2004)

Mourning ritual and performance wrap around each other in a spiral, feed each other and it is unwise to deprive them from this reciprocal nutrition. Should we learn to respect this ongoing consumption, we might once again take part and exclaim: "We had lots of fun at Finnegan's wake!" (Durnal, 1854).

\section{Conclusions}

There can be no doubt that absence is an element of performance which deserves to be acknowledged and understood as an entity that requires attention and care. By recognising the anxieties and taboos surrounding absence (in performance practices as well as life practices), it is possible to get closer to recognising the shortcomings of performance itself. Dispelling these taboos and defusing these anxieties can be achieved through establishing and maintaining a nuanced relationship with the tactile capabilities of the body intersecting with the sensual and sensitive qualities in mourning and mourning ritual. Reclaiming the allegiance between the tactile body and the processes of death and dying can therefore become a joyous methodology towards a strong and healthy relationship to absence in performance practices and beyond. 


\section{References}

Artaud, A., \& Serý, L. (1996). Surrealistické texty; Dopisy z Rodez; Prĭsluhovacì a trýzně. V Praze: Herrmann.

Bachelard, G. (2010). Poetika snění. Praha: Malvern.

Blanchot, M., \& Smock, A. (1995). The writing of the disaster = L'écriture du désastre. Lincoln: University of Nebraska Press.

Cohen, L. (2016). Treaty. On You want it darker. New York: Columbia. Retrieved from https://www.amazon.com/Treaty/dp/ B01LX7F6Z2

Durnal, J. (1854). Finnegans wake. Popular comic song. New York: John J. Daly, 419 Grand St. Retrieved from http://levysheetmusic.mse.jhu.edu/collection/052/003

Grotowski, J., \& Ertlová, B. (1999). Divadlo a rituál: texty 1965-1969. Bratislava: Kalligram.

Hejda, Z. (1985). Blizkosti smrti. München: Poezie Mimo Domov.

Kłossowicz, J., Kantor, T., Lexová, I., \& Hyvnar, J. (2017). Divadlo Tadeusze Kantora. Praha: Institut Umění - Divadelní Ústav.

Kolankiewicz, L. (1999). Dziady: teatr święta zmarłych. Gdańsk: Słowo, Obraz, Terytoria.

Levé, É. (2011). Suicide. Paris: Gallimard.

Maguire, L. (2016). Mourning, memory, and performance. Retrieved from https://blog.oup.com/2016/05/mourning-memoryperformance-shakespeare/

Navrátilová, A. (2004). Narozeni a smrt v české lidové kultuře. Praha: Vyšehrad.

Patočka, J., \& Polívka, L. (1995). Telo, společenství, jazyk, svět: ze záznamui prednášek proslovených ve skolním roce $1968-69$ na Filosofické fakultě Univerzity Karlovy. Praha: Ise.

Phelan, P. (2009). Mourning sex: Performing public memories. London: Routledge.

Pilátová, J. (1994). Odin Teatret - třicet let práce. Svět a Divadlo, 4/94, 68.

Pilátová, J. (2016). Seminar: Tělo v historii. Lecture notes. The Academy of Performing Arts in Prague, delivered October 18, 2016.

Pilátová, J. (2017). Seminar: Tělo v historii. Lecture notes. The Academy of Performing Arts in Prague, delivered October 24, 2017.

Rilke, R. M., \& Sabík, V. (1989). Piesne o láske a smrti (a iné básne). Bratislava: Slovenský Spisovatel.

Roach, J. (1996). Cities of the dead: Circum-Atlantic performance. New York, N.Y.: Columbia University Press.

Sofokles, \& Feldek, L. (1971). Antigona. Bratislava: Lita.

Strpka, I. (1985). Správy z jablka. Bratislava: Slovenský Spisovatel.

Ursíny, D. (1992). Vzývanie rodnej sestry. On Ten istý tanec. Prague: ARTA Records. Retrieved from https://hudba.drhorak.sk/ alba/1274/ten-isty-tanec/?idn=8 